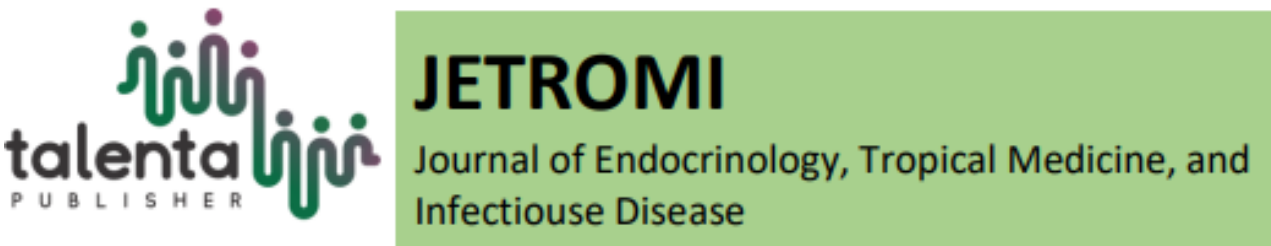

\title{
Effect of Salam leaf extract (Syzygium Polyanthum) to serum IL-10 levels on Acute Coronary Syndrome in Wistar Strain Mice Model
}

\section{Yulisa Astari Tanjung, Refli Hasan, Rahmad Isnanta \\ Division of Cardiology of Department of Internal Medicine, Faculty of Medicine, Universitas Sumatera Utara}

\begin{abstract}
Background Coronary Heart Disease (CHD) is one of the leading causes of death in developed and developing countries. Syzygium polyanthum leaf (daun salam) are reported to have anti-inflammatory, antioxidant, antidiabetic, antimicrobial, antihypertensive, antitumor, antidiarrheal, acetylcholinesterase inhibition, and lipase inhibitory activity. The purpose of this study was to prove the effect of bay leaf extract (Syzygium polyanthum) on serum interleukin (IL)-10 levels in the heart of Wistar Strain Mice Model of Acute Coronary Syndrome (ACS). Methods This is an experimental study to compare the IL-10 level in 32 ACS mice which were divided into 8 groups. Serum IL-10 values were collected and analyzed according to the corresponding group with and without bay leaf extract administration, on day 1,4,7, and 14. Result: There is an IL-10 value increasing with the duration of examination following the onset of ACS induction. The highest average IL-10 value was found on the 14th day, in the two groups. On the same day, it was seen that the treatment group had a higher IL-10 value compared to the control group $(\mathrm{p}<0.001)$. The result showed that the concentration of IL-10 was significantly greater among the treatment group, which reveal the potential benefit of bay leaf extract in patients with ACS. Conclusion: There was found a significant difference of serum IL-10 between Wistar Strain Mice Model of ACS that was given S. polyanthum leaf extracts. S. polyanthum leaf extract has quite extensive benefits in the cardiovascular system.
\end{abstract}

Keyword: ACS, Bay Leaf, Interleukin-10, Syzygium polyanthum

\begin{abstract}
Abstrak. Latar Belakang Penyakit Jantung Koroner (PJK) merupakan salah satu penyebab kematian utama di negara maju dan berkembang. Daun salam (Syzygium polyanthum) dilaporkan memiliki aktivitas antiinflamasi, antioksidan, antidiabetes, antimikroba, antihipertensi, antitumor, antidiare, penghambatan asetilkolinesterase, dan penghambatan lipase. Tujuan. Penelitian ini untuk membuktikan pengaruh ekstrak daun salam (Syzygium polyanthum) terhadap kadar interleukin serum (IL) -10 pada jantung mencit model sindroma coroner akut (SKA). Metode Penelitian ini merupakan penelitian eksperimental untuk membandingkan kadar IL-10 pada 32 mencit SKA yang dibagi menjadi 8 kelompok. Nilai IL-10 serum dikumpulkan dan dianalisis pada hari ke 1,4,7, dan 14, sesuai kelompok dengan dan tanpa pemberian ekstrak daun salam. Hasil: Terjadi peningkatan nilai IL-10 sesuai lama waktu pemeriksaan mengikuti permulaan induksi SKA. Nilai rata-rata IL-10 tertinggi ditemukan pada hari ke-14, pada kedua kelompok. Pada hari kelompok perlakuan memiliki nilai IL-10 yang lebih tinggi dibandingkan dengan kelompok kontrol $(\mathrm{p}<0,001)$. Hasil penelitian ini menunjukkan bahwa konsentrasi IL-10 secara signifikan lebih besar pada kelompok perlakuan, yang menunjukkan adanya potensi manfaat ekstrak daun salam. Kesimpulan: Ditemukan perbedaan yang signifikan IL-10 serum antara Mencit Wistar
\end{abstract}

${ }^{*}$ Corresponding author at: Department of Internal Medicine, Faculty of Medicine, Universitas Sumatera Utara 
Model SKA yang diberi ekstrak daun S. polyanthum. Ekstrak daun S. polyanthum memiliki manfaat yang luas terhadap sistem kardiovaskular. Kata Kunci: Daun Salam, Interleukin-10, Sindroma Koroner Akut, Syzygium
polyanthum

Received 05 July 2020 | Revised 24 August 2020 | Accepted 28 August 2020

\section{Introduction}

Coronary Heart Disease (CHD) is one of the leading causes of death in developed and developing countries, including Indonesia. This disease shows progression throughout the years, especially with the availability of diagnostic facilities.[1] Data in Indonesia according to the Riset Kesehatan Dasar (RISKESDAS) in 2018 showed that the prevalence of cardiovascular disease increases with age.[2]

IL-10 is an immunoregulatory cytokine produced by various types of cells, including activated monocytes, macrophages, and lymphocytes. IL-10 has many anti-inflammatory properties and has been shown to have a protective role, both in the formation of atherosclerotic lesions and their stability reported in animal studies. A study conducted in ACS patients suggests that IL-10 biological action demonstrates a protective role both in atherogenesis and plaque susceptibility.[3] A study in patients with ACS found that elevated IL-10 levels at baseline were a strong and independent predictor of reduced risk of death and myocardial infarction at 6 months of follow-up.[4]

S. polyanthum or locally called bay leaf (daun salam) is a plant that has been well known by the community, and is widely used as spice or flavoring because it has a distinctive aroma. In addition, bay leaves are also used for alternative medicine because these plants are easily obtained and considered efficacious. Bay leaves are known as salam in Java, Madura, and Sunda, kastolam in Kangean and Sumenep, manting in Java, and meselengan in Sumatra.[5]

An initial phytochemical screening study conducted by Kusuma et al revealed that the raw leaves and fruits of $S$. polyanthum contain carbohydrates, tannins, alkaloids, steroids, triterpenoids, and flavonoids, while mature fruits contain saponins, carbohydrates, tannins, alkaloids, triterpenoids, and flavonoids.[6]

At present, S. polyanthum leaves are reported to have anti-inflammatory, antioxidant, antidiabetic, antimicrobial, antihypertensive, antitumor, antidiarrheal, acetylcholinesterase inhibition, and lipase inhibitory activity.[7] S. polyanthum leaf extract can also reduce heart inflammation caused by myocardial infarction in a mouse 
model, reflected by a decrease in levels of C-reactive protein and Myeloperoxidase. [8] Recent study by Hasan et al showed that there were significant increases in IL-10 level since day 1 in ACS model mice treated with S. polyanthum leaf extract.[8]

The purpose of this study was to prove the effect of bay leaf extract (S. Polyanthum) on IL-10 levels in the heart of Wistar Strain Mice Model of ACS.

\section{Methods}

This was an experimental research using posttest with control group design. IL-10 levels can be assessed through plasma. In humans it is difficult to carry out conditioning of a homogeneous ACS and due to ethical reasons so as to determine the effect of giving bay leaf extract (S. Polyanthum) used an experimental animal model of ACS. The experimental animal used in this study was Wistar strain white rat (Rattus norvergicus, sp). This study used ACS model mice which are grouped into a control group and an experimental group. The control group was provided because of the high mortality risk of ACS model used and to reduce treatment bias on the same subject.

The research was conducted at the Department of Biochemistry and Molecular Biology, Faculty of Medicine, Universitas Brawijaya, Malang during November 2019 - February 2020.

Based on the results of sample calculation, the number of samples for each treatment group is 4 samples. The procedure of the ACS model and bay leaf extract follows the method mentioned in similar research by Hasan et al [8]. The procedure of making the bay leaf extract started first by taking the plants taken from one location only. The plants were then washed and the leaves were dried naturally under direct sunlight or aerated and then stored in a suitabale container. The leaf ethanol extract was prepared by maceration method by weighing $300 \mathrm{~g}$ of bay leaf simplicial powder, then placing it in a closed container (macerator), adding 3 liters of $70 \%$ ethanol. It would then needed to be stirred for the first 6 hours and let stand for 18 hours, stirred occasionally. Afterwards, it was filtered using cotton and filter paper, and the filrtare was collected (macerate I). The waste obtained was put back into the macerator container, and then $70 \%$ ethanol was added as much as half of the extraction volume I. Then the maceration process was repeated by soaking, stirring, settling and filtering to obtain macerate II. The next step was to mix macerate I and macerate II, then steam the macerate using a Rotavapor tool at a temperature of $40^{\circ} \mathrm{C}$, until a thick extract was obtained. Enter the thick extract into a plastic pot then label it. The extract was dissolved in a $0.5 \%$ carboxyl methyl cellulose sodium (CMC-Na) suspension solution and administered through a nasogastric 
tube (using a syringe). The control group was given the same volume of normal saline solution through a nasogastric tube (using a syringe)

The sample will be divided into 8 randomly selected groups (4 groups as control and 4 others as treatment groups, who will undergo examinations on day 1, 4, 7, and 14). The first group was ACS group that did not receive any intervention and was examined for the serum IL-10 on day 1 . The second group was ACS group that received S. polyanthum leaf extract and was examined for the serum IL-10 on day 2. The thirrd group was ACS group that did not receive any intevention and was examined for the serum IL-10 on day 4. The fourth group was ACS group that received $S$. polyanthum leaf extract and was examined for the serum IL-10 on day 4. The fifth group was ACS group that did not receive any intervention and was examined for the serum IL-10 on day 7. The sixth group was ACS group that did not receive any intervention and was examined for the serum IL10 on day 14. The last group was ACS group that received S. polyanthum leaf extract and was examined for the serum IL-10 on day 14. The serum IL-10 levels were examined using the enzyme-linked immunosorbent assay (ELISA) method from blood samples.

All data obtained in this study were collected and explained on each variable obtained. The ANOVA test was used to find significant mean differences between groups of samples. The $\mathrm{p}$ value that was considered significant was $<0.05$. Post-hoc test will be conducted following significant result.

\section{Results}

This study used 32 mice which were divided into 8 groups. Serum IL-10 values were collected and analyzed according to the corresponding group. Prior to the one-way ANOVA test, we conducted Lavene's test of equality of error variance, resulted in 0.138 significance value which indicates that the data were eligible to one-way ANOVA test. Details were presented in table 1. 
Table 1 The effect of S. polyanthum extract on Serum IL-10

\begin{tabular}{cll}
\hline Group & $\begin{array}{l}\text { Serum IL-10 }(\mathbf{n g} / \mathbf{m L}) \\
(\mathbf{m e a n} \pm \mathbf{S D})\end{array}$ & $\mathbf{p}$ \\
\hline Control & & $<0.001^{*}$ \\
Day 1 & $5.00 \pm 1.73$ & \\
Day 4 & $7.45 \pm 0.57$ & \\
Day 7 & $8.67 \pm 2.78$ & \\
Day 14 & $11.94 \pm 4.03$ & \\
Treatment & \\
Day 1 & $12.34 \pm 3.65$ & \\
Day 4 & $19.32 \pm 3.12$ & \\
Day 7 & $31.93 \pm 9.38$ \\
Day 14 & $33.63 \pm 4.82$ \\
*one-way ANOVA
\end{tabular}

In Table 1 it can be seen that there is an IL-10 value increasing with the duration of examination following the onset of ACS induction. The highest average IL-10 value was found on the 14th day, in the two groups. On the same day, it was seen that the treatment group had a higher IL-10 value compared to the control group. One-way ANOVA statistical test results yield a p-value $<0.001$ which shows the statistical significance of this result.

Following the significant result of the one-way ANOVA, we conducted a post-hoc test using Turkey HSD method to determine which of the groups has significant difference. The result were showed in Table 2.

Table 2 Post-hoc analysis between control and treatment group (p-value)

\begin{tabular}{lcccc}
\hline \multicolumn{5}{c}{ Treatment Group } \\
Control Group & Day 1 & Day 4 & Day 7 & Day 14 \\
\hline Day 1 & 0.51 & $0.02^{*}$ & $0.00^{*}$ & $0.00^{*}$ \\
Day 4 & 0.87 & 0.07 & $0.00^{*}$ & $0.00^{*}$ \\
Day 7 & 0.96 & 0.13 & $0.00^{*}$ & $0.00^{*}$ \\
Day 14 & 1.00 & 0.50 & $0.01^{*}$ & $0.00^{*}$ \\
& & & & \\
* value $<0.05$ considered significant & &
\end{tabular}


Post-hoc analysis showed that most of the differences between control and treatment group were significant at day 7 and day 14, suggesting that the effect of the treatment began to appear at day 7 .

\section{Discussion}

Coronary atherosclerosis, also known as coronary heart disease, is caused by myocardial ischaemia, hypoxia, and necrosis due to stenosis or blocked arteries lumen secondary to coronary artery atherosclerosis. Myocardial infarction is the most common type of heart disease. Many researchers hypothesize that the immune and inflammatory response is an important cause of coronary heart disease. The exact mechanism of action of IL-10 in atherosclerotic disorders and plaque formation has not been fully clarified. Potentially, this mechanism can involve inflammation downregulation, coagulation and matrix degradation. In addition, IL-10 has anti-apoptotic properties in various cell types, and it has been suggested that IL-10 can modulate plaque stability, at least in part, through antiapoptotic mechanisms. $[3,9,10]$

It appears that with the concentration measurement technique (ELISA), there was a significant increase in IL-10 levels in the ACS model with $S$. polyanthum leaf extract therapy. Based on research conducted S. polyanthum leaves contain steroid compounds, phenolics, saponins, flavonoids and alkaloids. $[11,12]$ The main compound contained in the leaves of $S$. polyanthum is flavonoids. Flavonoids are polyphenol compounds that have anti-inflammatory, anti-platelet, anti-cholesterol, anti-diabetes and anti-oxidant benefits. Flavonoids contained in the leaves of $S$. polyanthum are quercetin and fluoretin.[12,13] It is known that IL-10 will be regulated positively by macrophages, in the presence of steroids. This proves that flavonoid compounds and steroids in $S$. polyanthum leaves can increase IL-10 levels.

Previous studies on $S$. polyanthum leaf extract have been reported to have other cardiovascular benefits. Previous studies by Ismail et al [14] reported that water and methanol extracts of $S$. polyanthum leaves significantly lowered blood pressure in normal Wistar-Kyoto (WKY) mice and spontaneous hypertension by administering the extract intravenously. To achieve a simulation of traditional consumption methods, a more recent study by Ismail et al [15] examined the effects of S. polyanthum leaf extract given orally in WKY rats and conscious spontaneous hypertension, where the results of the study reported the administration of $S$. polyanthum leaf extract by oral route significantly reduces blood pressure in rats with spontaneous hypertension, but not in normal mice.[15] 
Regarding the mechanism of antihypertensive effect, studies have shown the possibility of $S$. polyanthum leaf extract to cause antihypertensive effects through vasorelaxation [16] and by inhibiting angiotensin-converting enzyme (ACE).[17]

Also related to the process of plaque formation, Prahastuti et al [13] reported that administration of $S$. polyanthum leaf extract reduced blood cholesterol levels in the dyslipidemic rats model, and there was no significant difference with simvastatin administration. Scchitano et al [18] in their systematic study concluded that various phytochemicals such as carotenoids, flavonoid polyphenols and non-flavonoids, have been reported to have a role in preventing dyslipidemia through various mechanisms, which will ultimately prevent atherosclerosis. S. polyanthum leaf extract can also reduce heart inflammation caused by myocardial infarction in mouse models, reflected by a decrease in levels of CRP and MPO.[8]

\section{Conclusion}

There was found a significant difference of serum IL-10 between Wistar Strain Mice Model of ACS that was given S. polyanthum leaf extracts. The IL-10 S. polyanthum leaf extract has quite extensive benefits in the cardiovascular system, but further research is needed to confirm further findings, and examine the side effects and toxicity before they can be used clinically.

\section{REFERENCES}

[1] World Health Organization. Library Cataloguing-Publication Data. Heart: Technical Package for Cardiovascular Disease Management in Primary Health Care. WHO Press.2016

[2] Departemen Kesehatan Republik Indonesia. Riset Kesehatan Dasar Jakarta: Badan Penelitian dan Pengembangan Kesehatan, Departemen Kesehatan Republik Indonesia.2018

[3] Flego D, Liuzzo G, Weyand CM, Crea F. Adaptive immunity dysregulation in acute coronary syndromes: from cellular and molecular basis to clinical implications. Journal of the American College of Cardiology. Nov 8;68(19):2107-17.2016

[4] Heeschen C, Dimmeler S, Hamm CW, Serum level of the antiinflammatory cytokine interleukin-10 is an important prognostic determinant in patients with acute coronary syndromes. Circulation.;107:2109-2114.2003 
[5] Kemenkes RI. Formularium Obat Herbal Asli Indonesia. Volume I. Jakarta: Kementerian Kesehatan RI. 2011

[6] Kusuma, I. W., Kuspradini, H., Arung, E. T., Aryani, F., Min, Y. H., Kim, J. S., et al. Biological Activity and Phytochemical Analysis of Three Indonesian Medicinal Plants, Murraya koenigii, Syzygium polyanthum and Zingiber purpurea. JAMS Journal of Acupuncture and Meridian Studies, 4(1), 75-79. 2011

[7] Ismail, A., \& Wan Ahmad, W. A. N. Syzygium polyanthum (Wight) Walp: A potential phytomedicine. Pharmacognosy Journal, 11(2), 429-438.2019

[8] Hasan, R., Lindarto, D., Siregar, G. A., \& Mukhtar, Z. The effect of bay leaf extract Syzygium polyanthum (Wight) Walp. on C-reactive protein (CRP) and myeloperoxidase (MPO) level in the heart of rat model of myocardial infarction. Medicinski Glasnik: Official Publication of the Medical Association of Zenica-Doboj Canton, Bosnia and Herzegovina, 17(1), 78-82. 2020

[9] Pérez Fernández R, Kaski JC. Interleukin-10 and coronary disease. Revista espanola de cardiologia. Jul 1;55(7):738-50. 2002

[10] Halvorsen, B., Wæhre, T., Scholz, H., Damås, J.K., Yndestad, A. and Aukrust, P. Role of interleukin-10 in atherogenesis and plaque stabilization. 2006.

[11] Liliwirianis, N., N. L. W. Musa, W. Z. W. M. Zain, J. Kassim, dan S. A. Karim. Preliminary Studies on Phytochemical Screening of Ulam and Fruit from Malaysia. EJournal of Chemistry 8 (S1). 2011

[12] Novira, P.P. and Febrina, E. Review Artikel: Tinjauan Aktivitas Farmakologi Ekstrak Daun Salam (Syzygium polyanthum). Farmaka, 16(2). 2018

[13] Prahastuti, S., Tjahjani, S., dan Hartini, E. Efek infusa daun salam (Syzgium polyantum) terhadap penurunan kadar kolesterol total darah tikus model dyslipidemia galur wistar. Jurnal Medika Planta, 1(4):29-32. 2011

[14] Ismail A, Mohamed M, Sulaiman SA, Wan Ahmad WA. Autonomic nervous system mediates the hypotensive effects of aqueous and residual methanolic extracts of Syzygium polyanthum (Wight) walp. Var. Polyanthum leaves in anaesthetized rats. Evid Based Complement Alternat Med;2013:716532.2013.

[15] Ismail A, Ramli NS, Mohamed M, Wan Ahmad WA. Acute and sub-acute antihypertensive effects of Syzygium polyanthum leaf extracts with determination of gallic acid using HPLC analysis. Pharmacogn J;10:663-71. 2018 
[16] Ismail A, Wan Ahmad WA. Autonomic receptors and nitric-oxide involvements in mediating vasorelaxation effect induced by Syzygium polyanthum leaves extract. Pharmacognosy Res;9:S9-14. 2017

[17] Muthia R, Suganda A, Sukandar E. Angiotensin-1 converting enzyme (ACE) inhibitory activity of several Indonesian medicinal plants. Res J Pharm Biol Chem Sci;8:192-9. 2017

[18] Scicchitano P, Cameli M, Maiello M, Modesti PA, Muiesan ML, Novo S, di Studio IG. Nutraceuticals and dyslipidaemia: beyond the common therapeutics. J Funct Foods.;6:11-32. 2014. 